\title{
Vento Forte
}

Strong Wind

\section{Heloisa Buarque de Hollanda}

Heloisa Buarque de Hollanda

Professora de teoria crítica da cultura na Universidade

Federal do Rio de Janeiro (UFRJ)

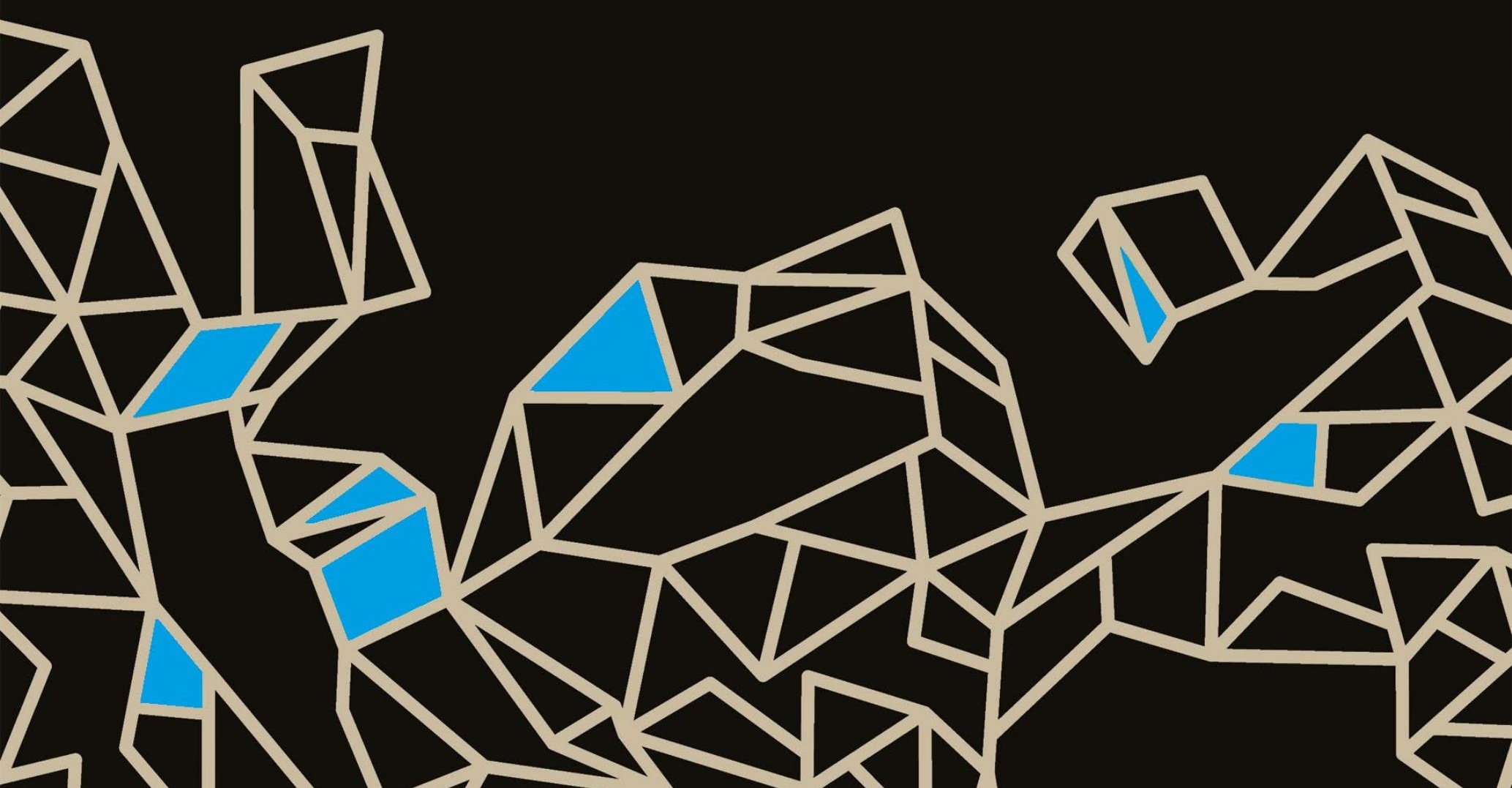


Quando fui convidada para participar deste número da revista Sala Preta, dedicado a José Celso Martinez Corrêa, viajei no tempo e voltei às dúvidas, inquietações e alegrias da exposição Ventos fortes, que fiz em comemoração aos 50 anos do Teatro Oficina. Isso foi em 2008, portanto, há mais de 10 anos. Como eu era amiga do Zé e, na minha juventude, fiel seguidora de todos os seus passos, esta realização foi uma viagem no tempo; agora viajo duplamente, em direção aos sentimentos que me atropelaram em 2008, mas também revisito minhas experiências como tiete radical do Oficina tropicalista. Um teatro agressivo, inimaginavelmente belo, que assustava e abria universos de imaginação, de crítica... Além de uma opção estética que nos atravessava para sempre. Essa era a memória que eu tinha do repertório do Oficina e das infinitas conversas que tive com Zé Celso.

Havia, ali, um debate sobre o Tropicalismo, mas confesso que não era isso que me interessava no quadro do aprendizado radical que o Oficina e seu Grande Mestre me ofereciam.

Disse isso tudo para contextualizar os sentimentos que orientaram a concepção de Ventos fortes, na efeméride de seus 50 anos. Será que eu conseguiria representar o impacto e a genialidade do Oficina? Comecei com o esperado: uma conversa com Hélio Eichbauer, meu amigo e o maior intérprete visual do ethos Zé Celso. As conversas com Hélio me deram a sensação de estar sonhando em reproduzir a estética e a dramatugia do Oficina, ou melhor, competir com o talento e a força do Zé. Deprimi. Dormi em cima do brainstorm com Hélio, e acordei certa de que esse jogo estava perdido. Parti para o oposto: uma exposição minimalista e documental com alguma referência ao imaginário-oficina. Chamei para a direção artística Alberto Renaut, que tinha formação em direção de ópera numa instituição italiana muito prestigiada. Achei que o barroco natural da ópera me traria José Celso de volta, ainda que numa ambientação radicalmente cool. Minha responsabilidade seria o compromisso com a precisão documental. Foi assim que examinei minuciosamente o vasto e precioso material do acervo Oficina. Sinceramente, não contava com o rigor e o cuidado do Oficina em registrar o processo de criação e de encenação de cada um dos espetáculos, estreados ou não (sim, vários projetos não chegaram ao palco). O acervo era impressionante. Vários pesquisadores e integrantes do próprio grupo se envolveram na difícil 
tarefa de selecionar o que mostrar. Foi penoso. Tudo era, literalmente, importante de ser mostrado. Os diversos suportes dessa memória eram fascinantes. Encontramos pilhas e pilhas de cadernos pessoais dos muitos integrantes de todas as épocas do grupo, manuscritos anotados e rasurados, repletos de desenhos em diferentes cores e texturas. Descobrimos filmagens de uma grande quantidade de ensaios e estreias. Além de figurinos, fragmentos de cenários... objetos aparentemente inexplicáveis e cadastros das mais díspares referências. A impressão era de estar tendo acesso a elementos imateriais de criação, segredos. Alberto Renault entendeu tudo na primeira visita. Partimos, mais seguros, para a exposição. $O$ resultado acalmou meus temores. Numa linguagem visual exageradamente contida, o exato contrário da retórica de José Celso, o Oficina explodiu em sentidos e informação.

A primeira sala foi montada num espaço totalmente escuro, com uma tela de 25 metros na qual o protagonismo do ator José Celso, montado com vários takes de antigos e novos espetáculos, saltava sobre o visitante. Assim, o primeiro impacto concentrava-se no talento altissonante de José Celso Martinez Corrêa, em solo, ecoando e dominando o ambiente. Esse era o tema da exposição.

Num primeiro braço/anexo, uma galeria de cadernos abertos em gráficos, desenhos, textos, fragmentos de falas, perfis de personagens em várias modulações, poemas, inscrições ininteligíveis, rabiscos em cor. No chão, um mar de pipocas branquíssimas cumprindo rituais atuados pelos integrantes do grupo em seus ensaios. Um segundo braço da exposição, outro mar, agora composto por pequenos monitores, dava acesso a uma grande quantidade de filmagens e registros visuais encontrados nos acervos, acompanhados de legendas informativas. Os monitores não dispensaram também alguns galhos de arruda, cujo uso era regra nos processos criativos do Oficina.

Vento forte era mais ou menos assim. O nome "vento forte" me pareceu expressar, com fidelidade, meu sentimento a cada estreia do grupo, a cada contato com eles ou com o Zé na minha juventude.

$\mathrm{Na}$ inauguração da exposição, Zé comemorou, à sua moda, derramando uma taça de vinho tinto na minha blusa de seda predileta. Até hoje, ainda não sei se senti alegria ou revolta. Como em meio a um vento forte. 


\section{Texto curatorial}

Vento forte para papagaio subir, texto de Zé Celso Martinez Corrêa e direção de Amir Haddad, foi a primeira montagem do grupo Oficina. Isso foi no dia 28 de outubro de 1958, há 50 anos.

Eu sentia e sabia que não poderia deixar de fazer alguma coisa sobre o Oficina naquele momento. Pensei numa exposição que registrasse o impacto da obra de José Celso que, durante esses 50 anos, vem criando e recriando a cultura brasileira.

Daí surgiu a primeira ansiedade: que exposição poderia ser essa, para mim, tão importante quanto ameaçadora? Como falar de Zé Celso, do Oficina? Como representar, com um mínimo de eficácia, esses ventos fortes que sopram em moto-continuo durante meio século?

Havia coisa demais a ser dita. Montagens que revolucionaram o universo cultural do país. Caminhos agitados que falam de grandes montagens, sucessos, polêmicas, invasões, incêndios, prisões, lutas violentas por território. O grupo Oficina, que já foi Cia. de Teatro Oficina, Oficina Samba, $5^{\circ}$ Tempo, Teatro Oficina Uzyna-Uzona. Foram várias etapas, várias histórias. Nunca passando em branco. Brigando sempre pela experimentação radical que desestrutura, transforma, que se mistura com a rua, com a multidão. Laboratório de mergulho nas origens, impõe o desejo como instrumento de criação, o corpo e a dança como funcionalidades primeiras. Criticado pela esquerda, censurado pela direita, a verdade é que ninguém da minha geração escapou do efeito Oficina. Do talento espantoso do poeta Zé Celso.

Sou prudente. Chamei Camila Mota, Lucas Weglinski - que se constituíram como as vozes do Oficina - e Alberto Renault - escritor, artista, diretor de ópera e peça central desse projeto -, e começamos a pensar juntos. $O$ título da exposição veio nos primeiros cinco segundos de jogo. Foi fácil. O conteúdo veio da lembrança de Camila da imensa documentação audiovisual, textual e iconográfica produzida desde o início do grupo por Zé e pelas equipes e elencos do Oficina e nunca tornada pública. Material inédito, bruto. Vídeos e filmes inteiros ainda desconhecidos. Cadernos de campo, belíssimos e densos, manifestos, documentos passeatas, anotações. Ou seja, o processo de criação e de luta do Oficina em cena aberta. Percebemos a urgência de mostrar esse 
material. Foi o que decidimos fazer. Alberto Renault optou por não teatralizar (ou competir com) o material e criou um ambiente limpo e techno no qual a dramaticidade revolucionária e interpelativa do Oficina pudesse surgir em solo. Uma ambientação sotto voce como o brilho do trabalho do mestre exige.

Foi assim que nos sentimos comemorando os 50 anos do Oficina. É isso que estamos oferecendo para o público já iniciado e para o público que não teve, ainda, a oportunidade de experimentar o Vento Forte Zé Celso Martinez Corrêa.

\section{Ficha técnica}

A mostra Ventos fortes - 50 anos do Teatro Oficina comemorou o centenário de criação do Grupo Oficina, liderado por José Celso Martinez Corrêa, e apresentou um extenso acervo da história do Oficina, incluindo vídeos de espetáculos e ensaios, roteiros, cadernos de anotações, cartazes, citações e fotos. Foi a primeira grande retrospectiva do Oficina no ano de seu aniversário de 50 anos. Quinze monitores de plasma, seis projetores e uma cabine de cinema foram usados para a projeção de imagens selecionadas de mais de 60 horas de filmagens das encenações de Boca de ouro, Bacantes, Ham-let, Cacilda e Os sertões, exibidas pela primeira vez. Em março de 2009, caixas especiais de DVDs com as gravações foram lançadas, com patrocínio da Petrobrás.

Concepção e curadoria - Heloísa Buarque de Hollanda

Curadoria - Camila Mota

Direção de arte - Alberto Renault

Abertura -3 de dezembro de 2008

Encerramento - 25 de janeiro de 2009

Local - Centro Cultural Correios no Rio de Janeiro

Autora convidada 


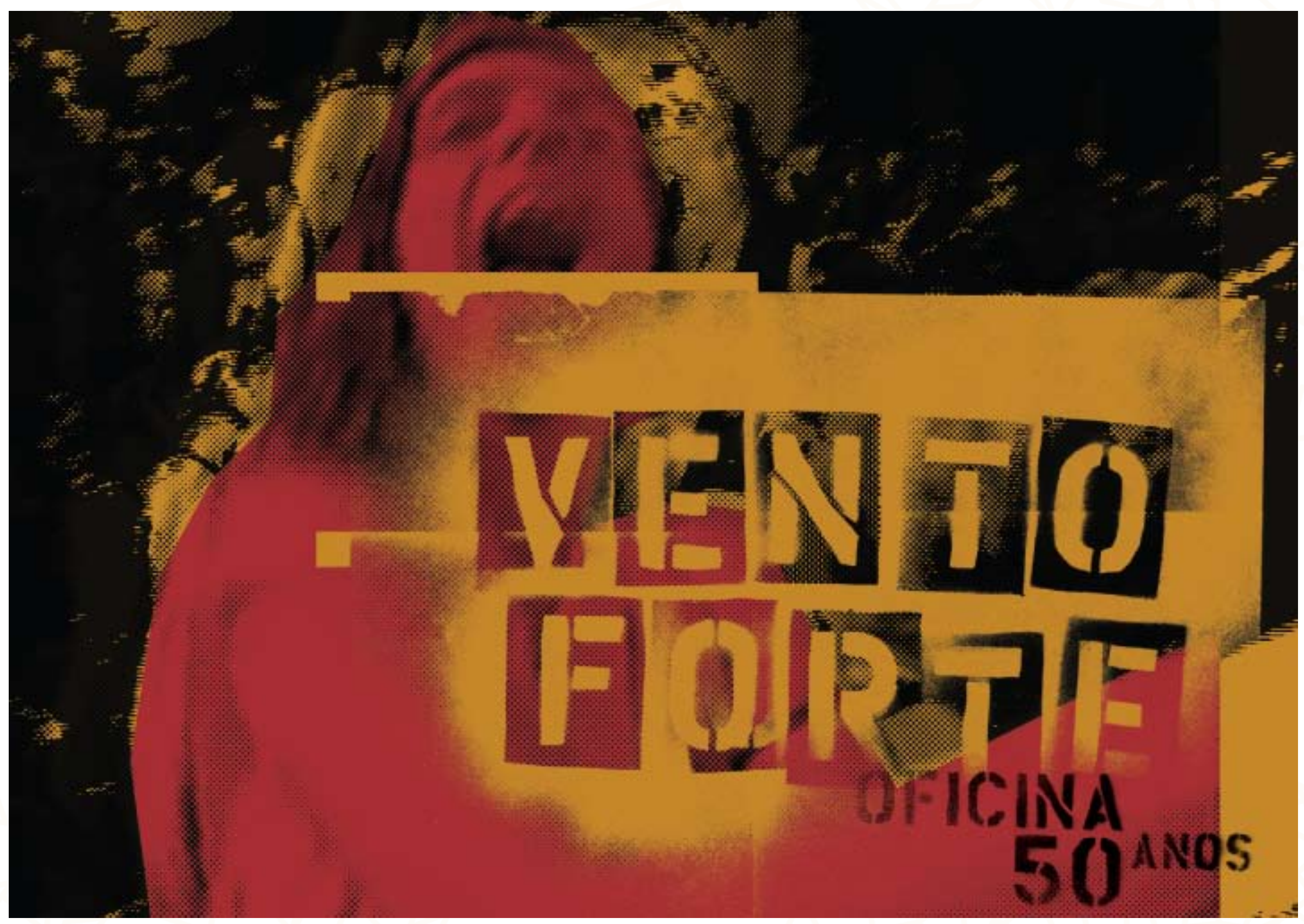




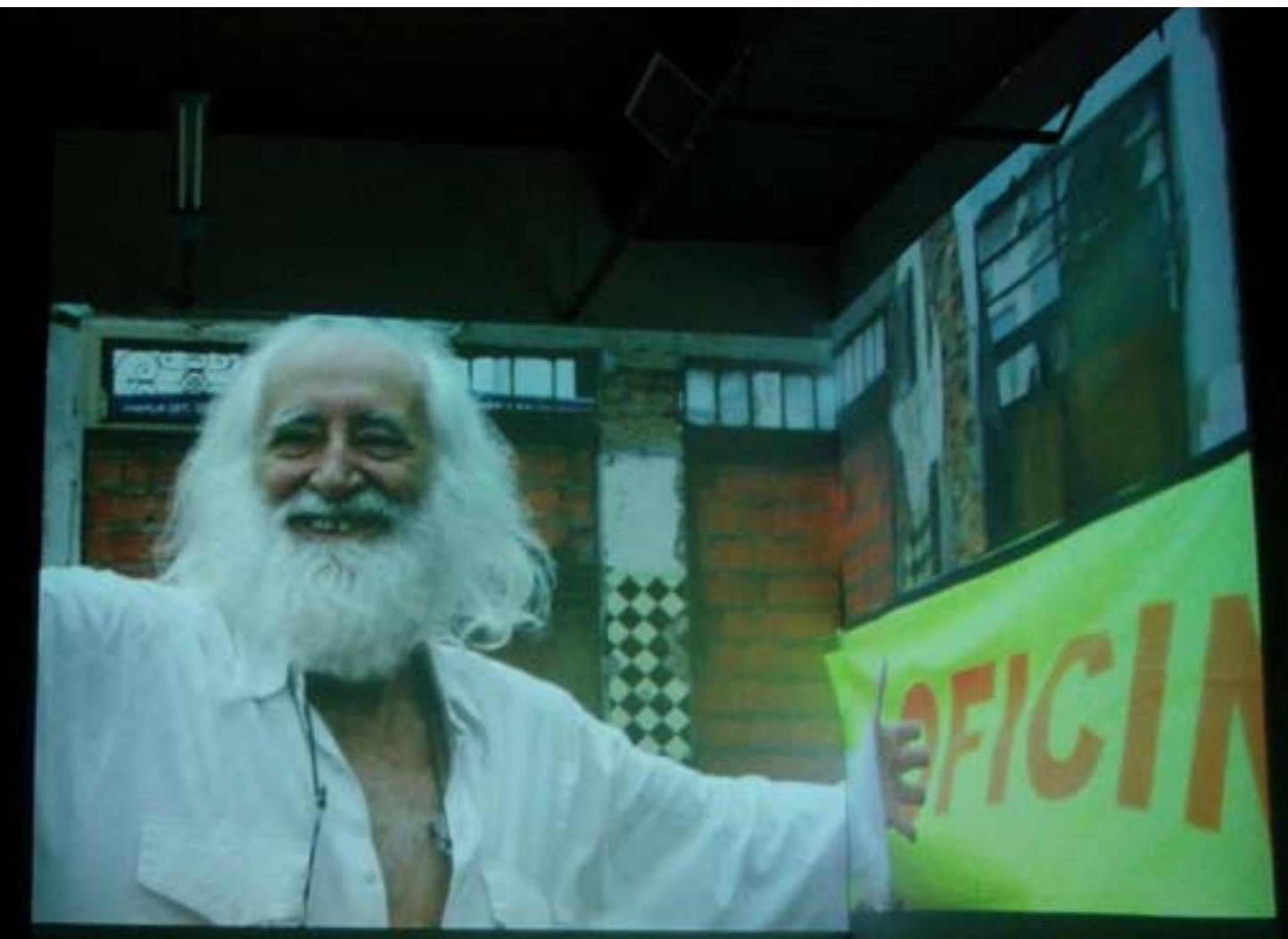

Vento Forte para Papagaio Subir, texto de Zé Celso Martinez Correa e direção de Amir Haddad , foi a primeira montagem do grupo Oficina. Isso foi no dia 28 de outubro de 1958, há 50 anos.

Essa é a hora de fazer justiça ao impacto da obra de José Celso que, durante esses 50 anos, vem criando e recriando a cultura brasileira. A hora de realizar uma exposição que representasse esses ventos fortes que sopram em moto continuo durante meio século.

0 material registrado e guardado por José Celso é inesgotável. Montagens que revolucionaram o universo cultural do país. Caminhos agitados que falam de grandes montagens, sucessos, polêmicas, invasões, incêndios, prisões, lutas 
violentas por território. 0 grupo Oficina que já foi Cia de Teatro Oficina, Oficina Samba , $5^{\circ}$ Tempo ,Teatro Oficina Uzyna-Uzona. Foram várias etapas, várias histórias. Nunca, passando em branco. Brigando sempre pela experimentação radical que desestrutura, transforma, que se mistura com a rua, com a multidão. Laboratório de mergulho nas origens, que impõe o desejo como instrumento de criação, o corpo e a dança como funcionalidades primeiras. Criticado pela esquerda, censurado pela direita, a verdade é que ninguém da minha geração escapou do efeito Oficina. Do talento espantoso do poeta Zé Celso.

Vento Forte é uma imersão na imensa documentação áudio-visual, textual e iconográfica sobre o Oficina e nunca tornada pública. Material inédito, bruto. Vídeos e filmes inteiros ainda desconhecidos. Cadernos de campo, belíssimos e densos, manifestos, documentos passeatas, anotações. Ou seja, o processo de criação e de luta do Oficina em cena aberta. Para isso criamos uma ambientação sotto voce como o brilho do trabalho do mestre exige.

É isto que estamos oferecendo para o público já iniciado e para o público que não teve ainda a oportunidade de experimentar o Vento Forte Zé Celso Martinez Correia.

Heloisa Buarque de Hollanda 
"Criar uma exposição sobre a obra de José Celso Martinez Correa feita toda ela de imagens, sons, corpos suados, catarses e fé no espaço rígido de uma sala de exposição é um desafio. Esta exposição optou pelo caminho da exploração do extenso acervo de imagens fotografadas, filmadas e gravadas nesses 50 anos de vidas do Teatro Oficina. Vida, que, diga-se de passagem, ocorreu "até" nos palcos, porque fora dele, em reuniões, passeatas, discussões, festas, ensaios, tombamentos e ruínas a história do Oficina aconteceu tanto quanto nas cenas das "Bacantes" ou dos "Sertões". Uma verdadeira "oficina de imagens" contadas através deste inestimável material imprescindível para contar a história da cultura recente brasileira. Foram mais de 100 horas de material editado, procurando eleger os momentos que melhor traduzissem a força hipnótica do ritual teatral do Teatro Oficina. Como curador, escolhi o conceito de uma página em branco - no caso uma grande caixa escura - para projetar as imagens selecionadas: 16 monitores de vídeos suspensos como que voando protegidas por ervas e sal grosso - paredes inteiras como suporte para a projeção dos vibrantes cadernos de anotações do grupo - vídeos com uma edição frenética e arrítmica - elementos do candomblé e da cultura popular mesclados a melhor tecnologia. Salas escuras e o brilho das imagens difundidas. Pontos de luz iluminam ervas e as as pipocas dos rituais, cenográficas e verdadeiras - um club underground ou um labirinto escuro onde brilharia e sopraria um vento forte. Zé Celso revendo com o público esse vento que há cinqưenta anos sopra, mais que vento, um furacão".

Alberto Renault 
VENTOS FORTES

EVOÉS AUDIOVISUAIS

DAS 50 CIRANDADAS EM TORNO DE SOL

DO CORPO SEM ORGÃOS DO UNIVERSO

ANIMAL VEGETAL MINERAL SIDERAL

HUMANO

TRANSHUMANO

DOS ASSOCIADOS

DOS PÚBLICOS

DA ASSOCIAÇÃO TEAT(r)OFICINAUZYNAUZONA

A $1^{\text {a }}$ DIONIZÍACA VIRTUAL

PARA

EM RECINTOS SAKRALIZADOS

ELEKTRIZAR OS CORPOS DOS VISITANTES

MASSAGEMEIOGEANDO-OS

DESDE O ÍNICIO

NOS VENTOS FORTES

Q BATIZARAM ESTA IN-EXPOSIC̣ÃO

OS EVOÉS DE OLURUM de

"Vento Forte para um Papagio Subir" estreado no dia 28 de outubro de 1958 em São Paulo, na Rua Jaceguay 520 no mesmo ESTRATOPORTO donde partiram e partem

os ventos iniciais e as naves deste Meio Século de História Viva em Movimento de Eterno Retorno

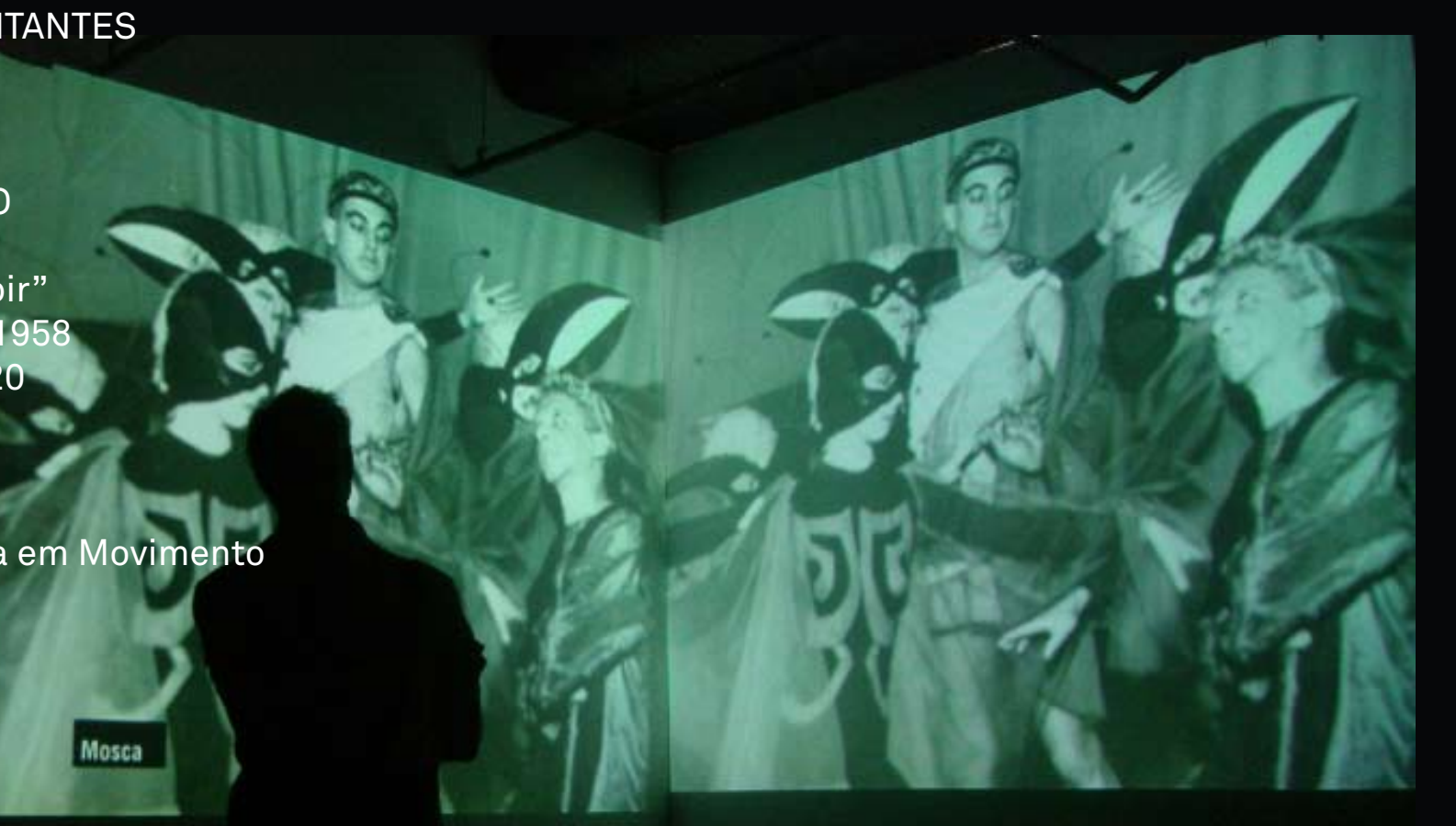


Imagens filmadas

- da peça re-encenada em 2007 em Araraquara - Aracoara em Tupy Morada do Sol

- da Companhia $1^{\circ}$ das Amizade Douradas

Da Cia de Teatro Oficina Ltda.

Criadora do $1^{\circ}$ Teatro Oficina

trechos de filmes

"O REI DA VELA"

GRACIAS SEÑOR,

(em várias filmagens, uma delas sem som)

GALILEU GALIEI

(Pequeno trecho)

- de Fotos, Desenhos, Cadernos de seus espetácu los

até a ruptura do Cordão das Amizades Douradas

no Acodar de 1972 para 1973 em

"AS TRÊS IRMÃS"

que legou a MANDALA que gira em caracóis

nos sentidos anti e horário num tempo de perfura-

ção do Beco ainda sem Saída

do Terreiro do OficinaUzynaUzona

- do Oficina Samba

em busca do Oficina $5^{\circ}$ Tempo

nos Subterrâneos do Brasil Militarizado

não se deixando capturar nem física, nem emocionalmente

apesar de Invasões Policiais, Torturas e Prisões

Exilando-se na Revolução Portuguesa

criando o filme "O PARTO"

na Descolonização de Moçambique trazendo

$1^{\circ}$ filme Festa de sua Independência no filme " 25 "

- do seu retorno do Exílio ao Brasil

na abertura longa restrita e gradual

em sua nova estrategía de

Oficina Virando Teat(r)o OficinaUzynaUzona

com os Núcleos:

\section{"OS SERTÕES"}

associados aos

Coros Sertanejos Nordestinos de SamPã

\section{"BACANTES "}

Coros de Jovens atuadores de todo Brazil, viradores do Símbolo da Bigorna Bicorneada do Oficina em Taça

\section{"O HOMEM E O CAVALO"}

Coros de CineVideoastas passando a captar todos os movimentos subjetivos objetivos de todos os núcleos

com seus "cavalos" câmeras de cinema e os primeiros UMATICS e VHS 
"ETERNO RETORNO À ANTROPOFAGÍA"

Coro de Memorialistas criando os primeiros Arquivos para serem Antropofagiados

do Acervo já Multi Mídias do Oficina.

\section{"ANHANGABAÚ DA FELICIDADE"}

Coro de Arquitetos, Urbanistas, jardineiros, peões, engenheiros, mestres de obra, lutando pela construção do Terreiro Eletroniko

da aquilina Lina Bardi,

depois unida à Edson Elito,

do Teat(r)o Pé Na Estrada, Rua,

dando pro Teatro de Estádio

Oca de Curvas Mirabolantes e Volutas Impossíveis, a Universidade Antropófoga, a Oficina de Florestas e reinterpretando o Minhocão

responsável pela destruição do Bixiga

como Ponto de Econtro Misturado

de Todos os São Paulos e SamPãs

criando em seus Baixos uma "ÁGORA",

Ponto de Encontro misturado cosmopolita de toda capital do Capital da maior cidade da América do Sul.

- Os Teatos filmados, gravados, para a conquista dos objetivos como a peça "As Boas"

com Raul Cortez de Madame

e Marcelo Drummond e Zé Celso de Empregadas

ou seja: Boas
- O Terreiro Eletrônico incompleto,

inaugurado dia 3 de outubro de 1993 com "Hamlet"

A partir daí juntamente com a revolução cyber cresce a Associação que grava a maioria de seus espetáculos, ensaios, reuniões, viagens...

Profissionalmente criando um objeto audio visual ainda nem identificado ou rotulado, uma nova maneira caleidoscópica de gravar o Teat(r)o com a presença de público, câmeras de cinema, muitas, captação sonora de altíssima qualidade "Ham-Let"/ "Cacilda!"/ "Boca de Ouro"/ "Bacantes"

"Os Sertões" "A Terra"/ " O Homem I"/

"O Homem II"/ "A Luta I"/ "A Luta II"

"Taniko"

"Vento Forte pra um Papagaio Subir"

"Cypriano y Chan-ta-lã"

"Os Bandidos"

tendo espetáculos como "Pra dar Um Fim no Juízo de Deus", "Os Mistérios Gozozos" e outros eventos com gravações q tem trechos presentes na Exposição VENTOS FORTES

O mais belo e maior presente do Cinquentenário Presente dado pela Musa das Musas de Calíope Arte da Poesia Épica 
de Clio a proclamadora da nossa história da amável Erato da Poesia Lyrica

da doadora de prazeres Música Euterpe de Melpômene da Poesia da Tragédia de Thaleia a que faz brotar flores da Comédia da rodopiante Terpsícore da Dança de Urânia a celestial Astrologa do compasso rítmico dos Dityrambos Dionisíacso dos astros da Polyhymnia a de muitos hinos

enfim a Bella Mestra das Letras da Universidade do Rio

Heloisa Buarque de Holanda

Inventora e co-criadora com Alberto Renault, com a automática nada autômata Luiza Mello, com os cyber maestros da montagem

Felipe e Gustavo

e os associados do Oficina Uzyna Uzona

o Satyro Lucas Weglinski e a Bacante Camila Mota

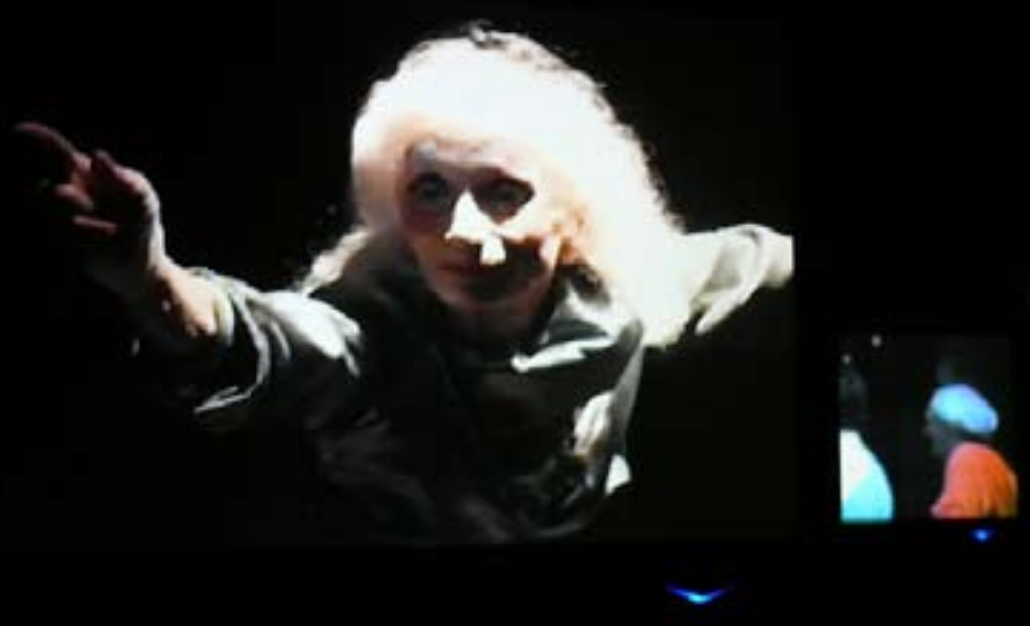

Os $1^{\circ} \mathrm{s}$ Korégas,

nome dado aos que tinham a honraria

nas Tragédias Gregas de patrocinarem os Coros foram os Correios do Brasil

Onde esta Exposição foi instalada pela primeira vez em seu Centro Cultural no Centro do Rio de Janeiro

Em São Paulo, o maior Koréga de SamPã, Danilo Miranda

traz para o SESC a primeira viagem desta

Dionisíaca Virtual

a ser disseminada, em terreiros virtuais pelo Globo Todo Plugado.

Os vestígios deixados e expostos dinamicamente em constante e atualizado enriquecimento dos "trabalhos" deste Meio Século em andamento buscam a transmissão deste Presente de Heloisa não somente para nós do Oficina Uzyna Uzona mas para tudo e todos.

EVOÉÉÉÉsssssssssss

José Celso Martinez Correa 
EXPOSIÇÃO VENTO FORTE OFICINA 50 ANOS

Centro Cultural dos Correios, Rio de Janeiro, 2008

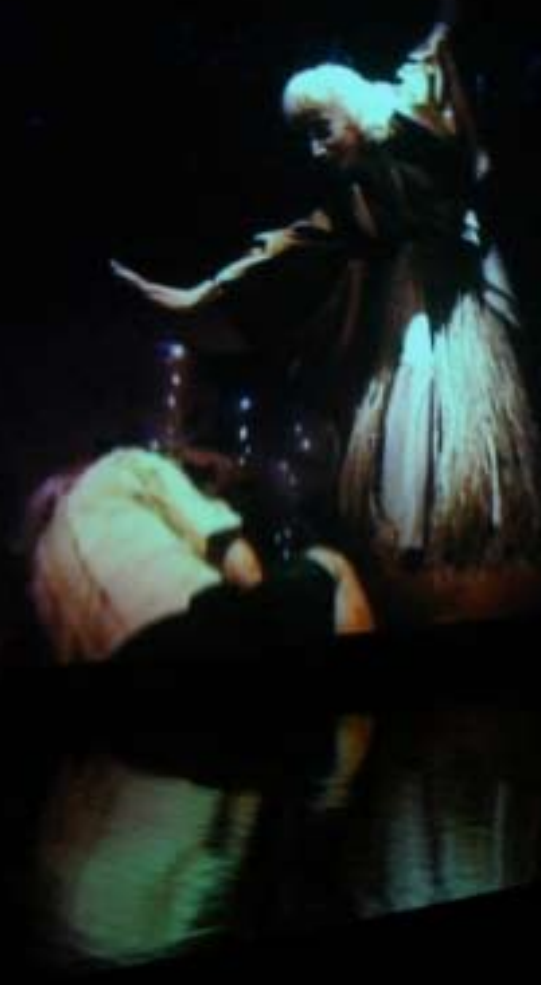

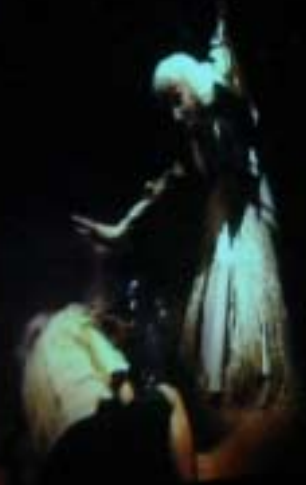

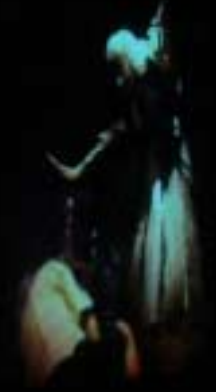

4 grandes vídeo-projeções com trechos editados de peças encenadas pelo Oficina. Duração: 60 minutos em loop Lista de peças:

O Rei da Vela, Galileu Galilei, Bacantes, A Terra, Hamlet, Cacilda e Os Sertões. 


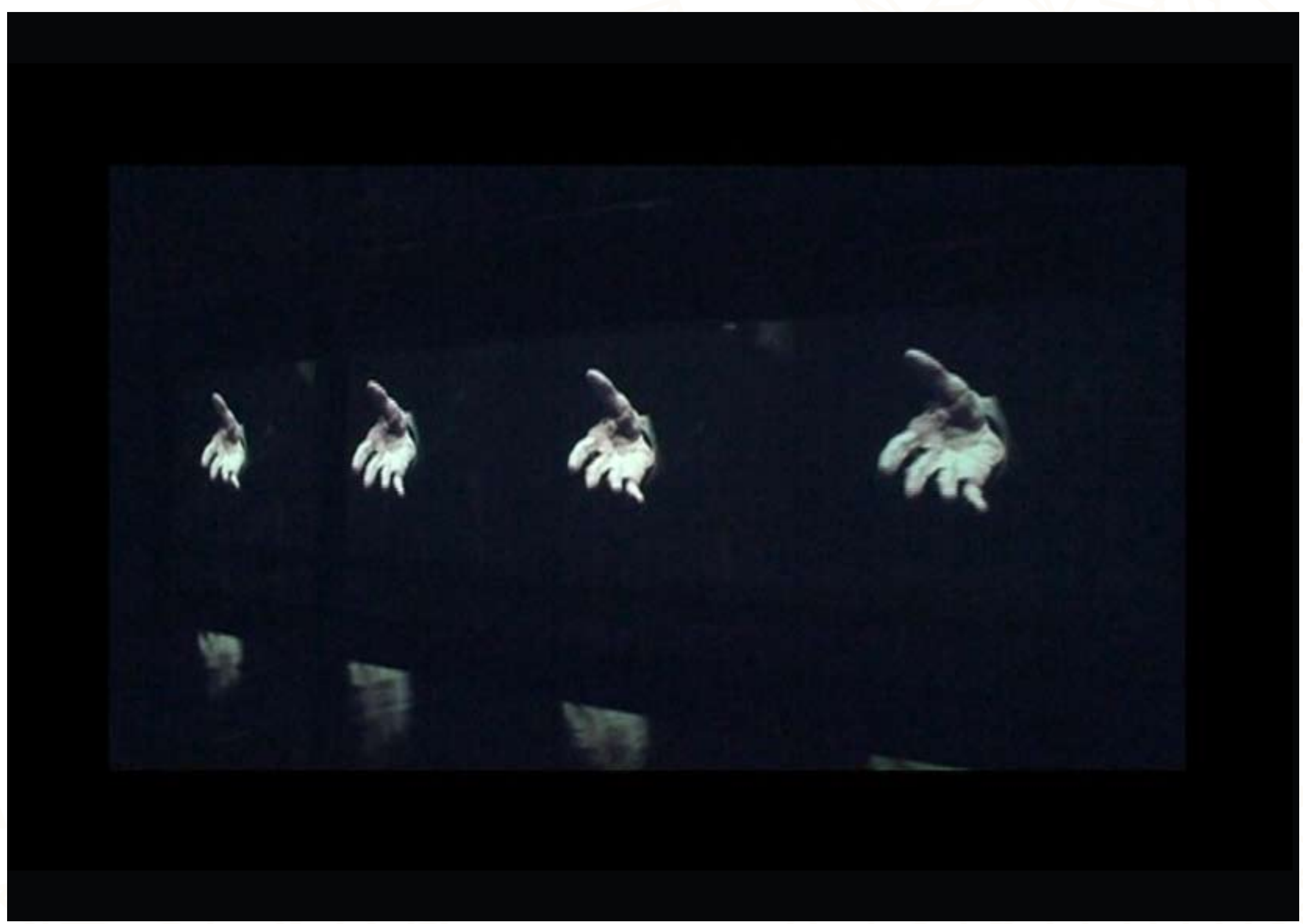




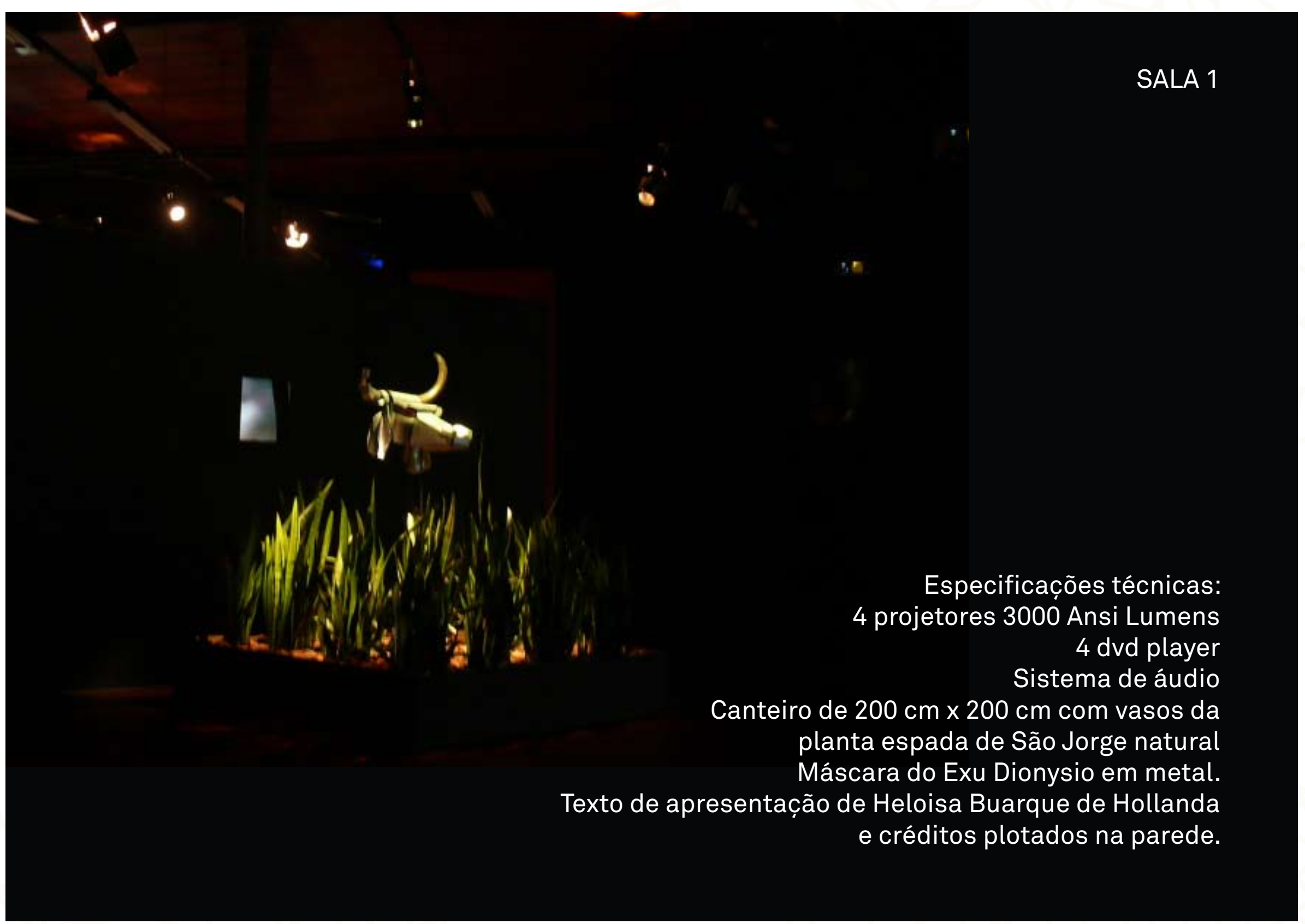




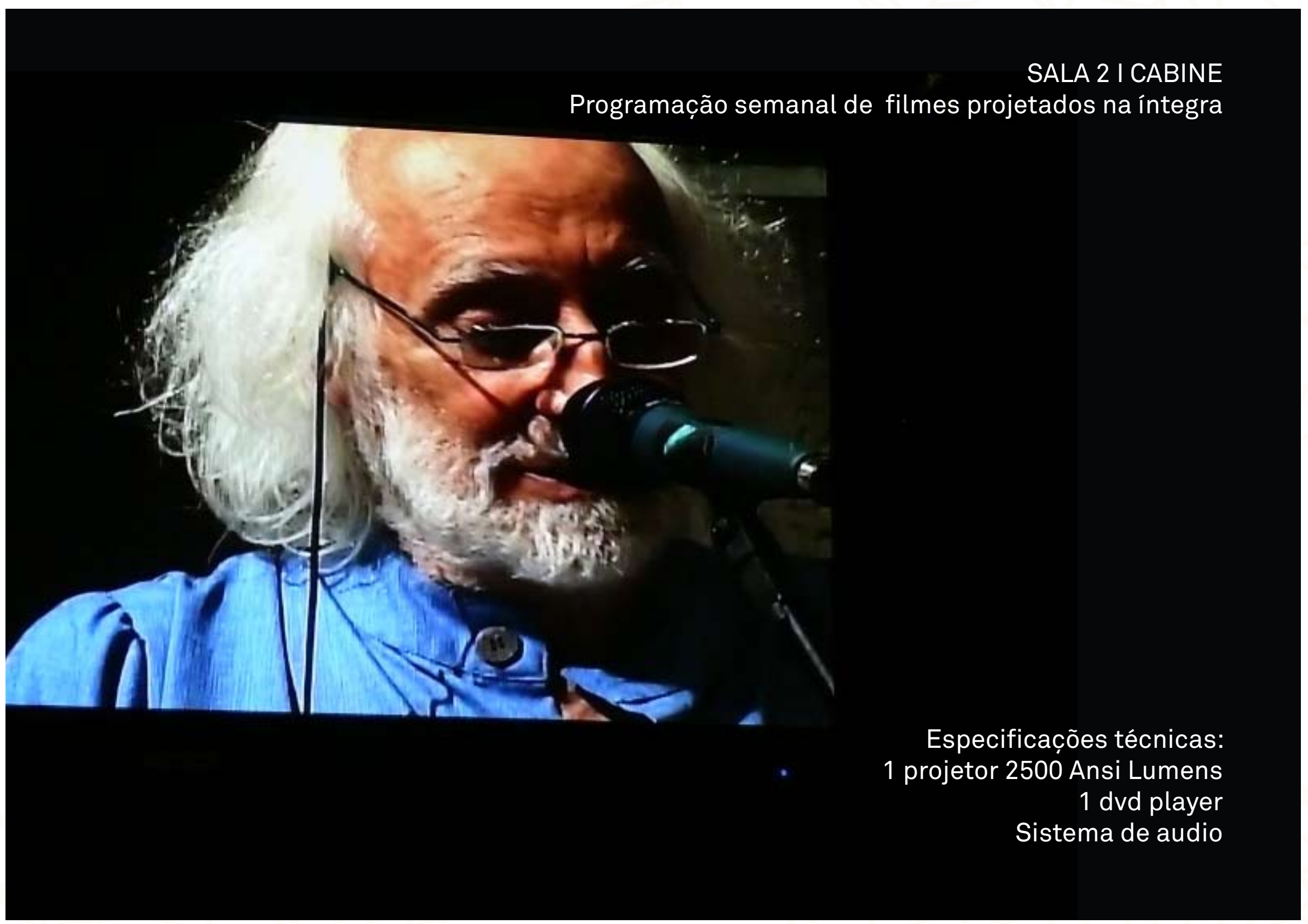


1. BACANTES

2. BOCA DE OURO

3. EXTRAS do DVD de HAM-LET

4. Teatro Oficina, o documentário - 34'05"

5. Entrevista com Zé Celso - 28'52"

6. FESTA DO $50^{\circ}$ - PARTES 1 e 3

7. FESTA DO $50^{\circ}$ - PARTE 4

8. FESTA DO $50^{\circ}$ - PARTE 2

9. HAM-LET, de William Shakespeare

10. CACILDA! de José Celso Martinez Correa

11. Anhagabaú da Feliz Cidade

12. José Celso e Jurema Preta (1h 10')

13. Entrevista José Celso (46' 47')

14. BEXIGA // SAMBA (1h 05' 38'")

15. A Terra, Ato 1 (1h 24' 57')

16. O Rei da Vela (2h 40' $\left.39^{\prime \prime}\right)$

17. Rito Orgya (9'48"')

18. História do Oficina, 1980-1984 (2h 00’35”) 
16 monitores de lcd de diferentes tamanhos com fones de ouvido. Cada monitor apresentava edições de vídeos de diferentes momentos da história do Teatro Oficina.

Em cima dos suportes dos monitores, copos com água e ervas (manjericão, hortelã e alecrim).

Especificações técnicas:

16 monitores de lcod de diferentes tamanhos

16 dvd player

32 fones de ouvido.

16 suportes para monitores

16 copos de vidro com água e ervas

(manutenção 2 a 3 vezes por semana)
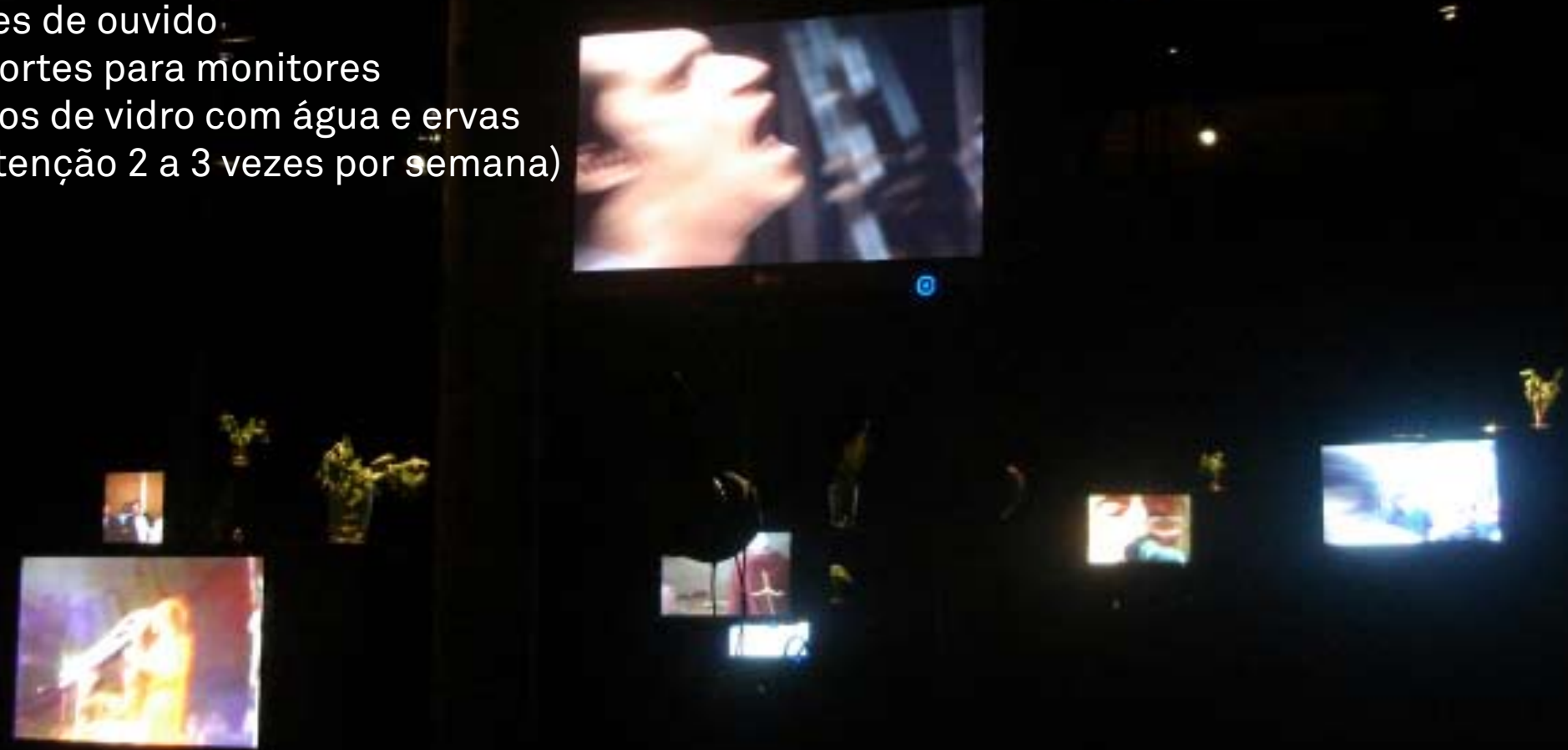


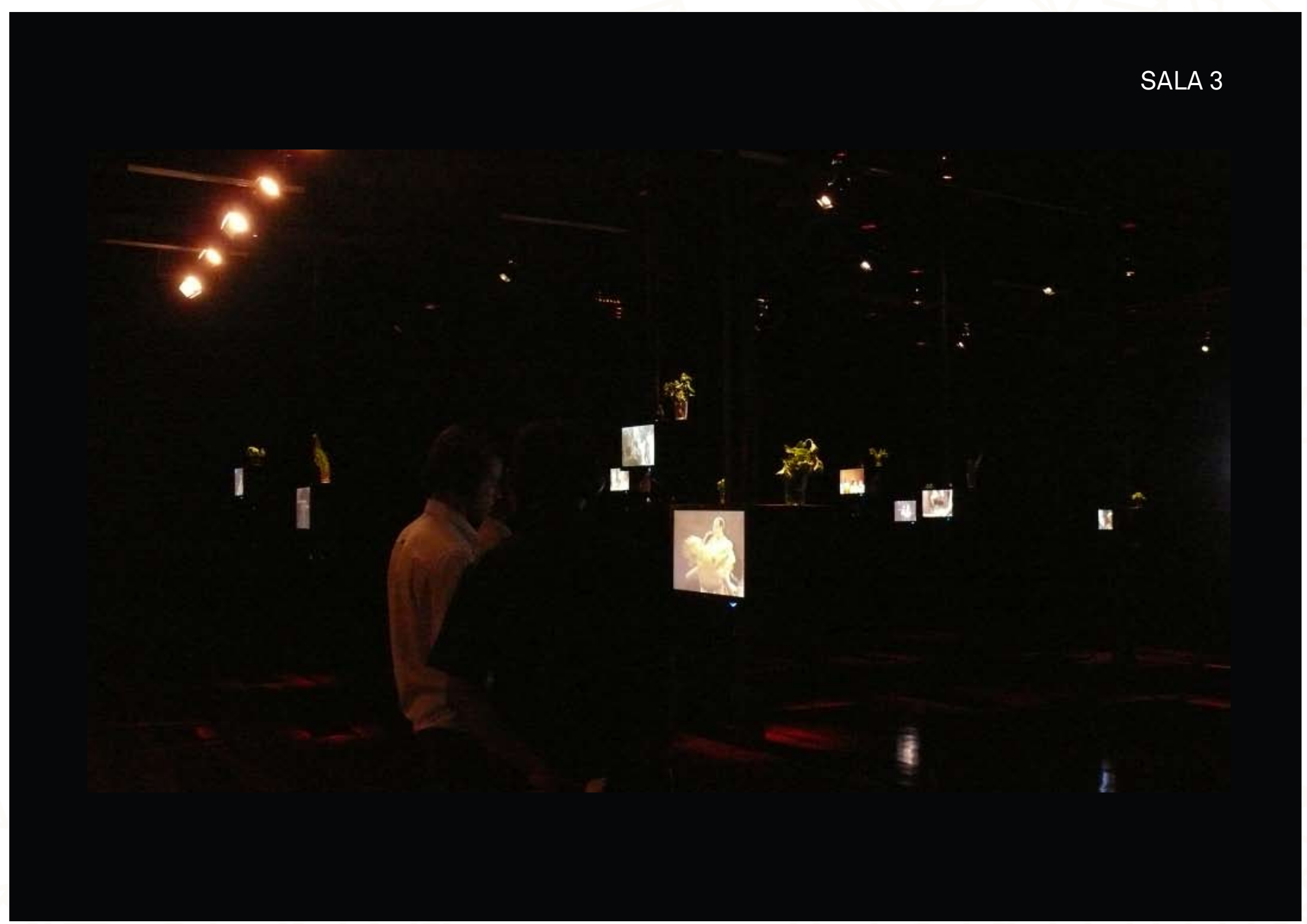




\section{FILMES}

1- Cenas de Bacantes em Ribeirão Preto 1995

Duração: 07:02

Cenas de Bacantes em Ribeirão Preto em agosto de 1995.

A estréia desse espetáculo foi no maravilhoso Teatro de Arena de Ribeirão. Um anfiteatro ao ar livre, lotado, com mais de 4 mil pessoas presentes.

O público delira nas cenas em que os atores invadem a platéia.

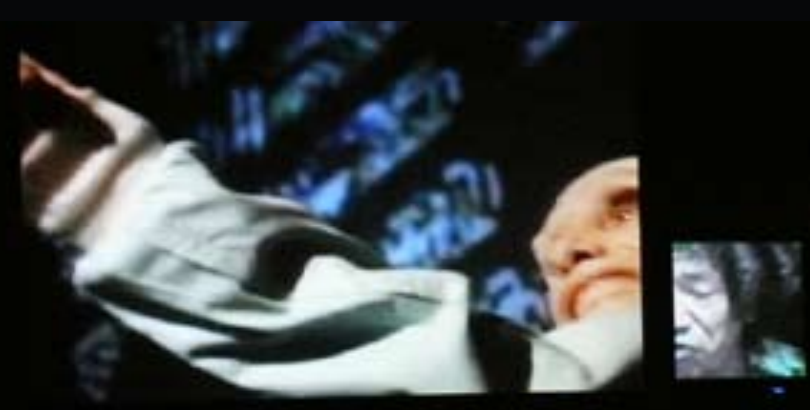

$\sim$
2- Ensaios

Bacantes - 1996

Luta 1 - 2004/05

Mistérios Gozozos - 1995

Duração: 13'23'"

Bacantes. 1996.

Zé Celso ensaia os atores Marcelo Drummond, Pascoal da Conceição, Leona Cavalli, Lúcia Gayoto, Adriana Capparelli, Patrícia Winceski, Vera Barreto Leite, Fransérgio Araújo, Fabiana Serroni, Franklin Albuquerque. Faz comentários e dá direções para as cenas do canto do Bode, do estraçalhamento de Dionysius.

Estraçalhamento do Bode.

Luta 1. 2004/05.

Ensaio da ópera de Arlindo Leone, personagem de Ricardo Bittencourt, protagonista do prólogo da Luta.

Mistérios gozozos. 1995.

Mais de quinhentos atores de São Paulo atenderam ao chamado do jornal para a sessão de trabalho que selecionaria o elenco para este espetáculo de Oswald de Andrade. Foi um episódio famoso e cheio de lendas, como a do casal que fez sexo nesse dia. Os trabalhos neste trecho selecionado são comandados por Pascoal da Conceição. As imagens alternam-se com cenas do espetáculo montado. 
1983

Duração: 10'02"

Abertura do vídeo Caderneta de campo.

A Cia Teatro Oficina adentra cantando, em 1983, os estúdios da Fundação Padre Anchieta, para gravação do vídeo Caderneta de campo, com inspirações em Bacantes, Mistérios gozozos, Os sertões.

Esta obra, produção da TV Cultura, foi censurada e nunca passou naquela emissora.

4- Maria Alice Vergueiro e Catherine Hirsch 1983/2008

Duração: 10'02"

Reunião no Teatro, que se encontrava em precárias condições.

A batalha dos atuadores para conseguir os recursos necessários

para reforma e manutenção da Cia era incessante. Aqui, Catherine Hirsch, Maria Alice Vergueiro, Zuria e Zé Celso discutem o que fazer.

Na seqüência, Maria Alice canta o tango do marinheiro, no dia da comemoração do $50^{\circ}$ do Teatro, 28 de outubro de 2008, em um Oficina lotado.

\section{SALA 3}

5- Serendipity

Visita de Silvio Santos

2004

Duração: 04'40"

Esta palavra foi apresentada ao grupo por Eduardo Suplicy,

que propiciou, no dia 18 de abril de 2004, a visita de Silvio Santos ao Teatro Oficina. Essa palavra pode também ser traduzida por meio de um dos cantos de Bacantes: "pro inesperado os deuses sempre abrem caminho".

Apresentamos os momentos iniciais e finais desse encontro, que inaugurou o diálogo, até então inexistente, entre os vizinhos do Bixiga.

6- Festa no Parque do Ibirapuera em prol do tombamento

Depoimentos de Ítala Nandi e Caetano Veloso 1980

Duração: 08'13"

Em dezembro de 1980, houve uma festa pública, com shows no Parque do lbirapuera, em prol do tombamento do Teatro Oficina, ainda ameaçado de compra pelo Grupo Silvio Santos.

Trechos do show de Caetano Veloso e depoimentos dele e de Ítala Nandi. 


\section{SALA 3}

7- Renée Gumiel

Entrevistas em 2004/2005/2006

Duração: 09'40"'

Dançarina francesa, trabalhou muitos anos na Cia. Morreu em setembro de 2006.Trabalhou até duas semanas antes de sua morte nos espetáculos de Os sertões.Trechos da Luta 2, Terra, Homem 1 em agosto de 2006 e entrevista com ela em Berlim em 2005, durante as apresentações da saga de Euclides da Cunha e no avião pra Reckinghausen em 2004.

8- Orquestra dos pedreiros nas obras

do Teatro Oficina

1983

Duração: 06'33'"

Sandy Celeste canta Para ver a luz do sol, de Edgard Ferreira; Surubim canta Todas descidas não são ladeiras; Maria Alice Vergueiro canta Primavera, todos acompanhados pela orquestra dos pedreiros que trabalhavam nas obras do Teatro Oficina.
9- Demolição e Pomba Gira

1982

Duração: 04'34"'

Cenas da demolição do entorno na rua da Abolição e cenas do trabalho da pombajira, durante a obra de Surubim para tirar o antigo palco giratório que estava podre. Ela dá a Catherine Hirsch explicações sobre eguns.

10- Entrevista TV Manchete

Lançamento do filme 0 Rei da Vela 1983

Duração: 06’’0”'

Cinqüenta anos depois de escrita a peça, é lançado o filme 0 rei da vela.

Rede Manchete entrevista Zé Celso e Surubim. Final da ditadura, início do processo democrático, ainda com expectativa para eleger diretamente o sucessor de Figueiredo.Os personagens de Oswald, Abelardo $1^{\circ}$ e $2^{\circ}$, são apresentados. Na figura de Abelardo $2^{\circ}$, Zé pressagia a ascensão de um personagem tấo-ạstrador e censor como o governo militar: a burgh neoliberalista.
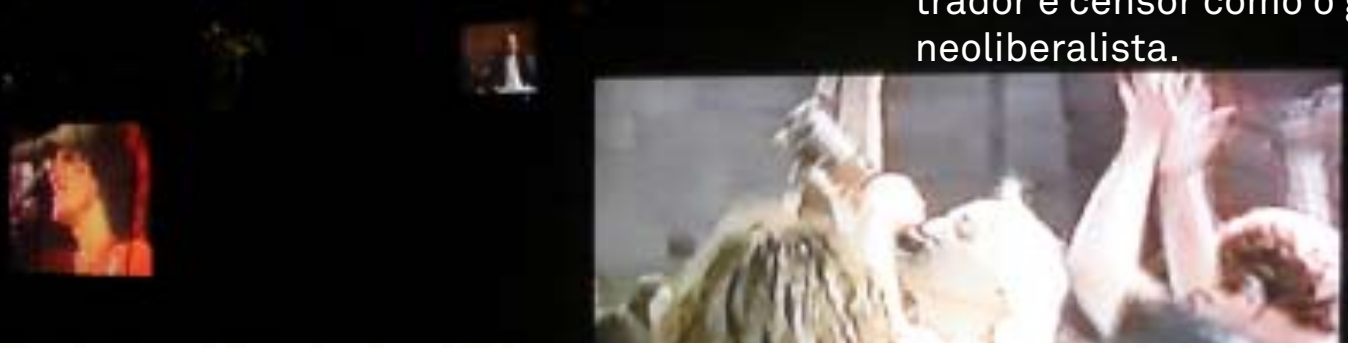

E. 
SALA 3

11- Passeata Cirandando

Desapropriação

1983

Duração: 13'16"

No ritmo icto toré da ciranda de Surubim,em 3 de fevereiro de 1983, atuadores do Teatro Oficina saem em passeata até a Secretaria de Estado da Cultura, para encontrar João Carlos Martins e entregar um documento que apresenta as condições e necessidades do teatro, que, en 11 de dezembro de 1982, havia sido tombado mas ainda não desapropriado.

As imagens desse dia são intercalladas com as cenás da demolição do entorno oeste do teatro, que incluía uma sinagoga. Máquinas pesadas derrubam o casario, no dia 25 de janeiro de 2004, enquanto acaidade festejava os 450 anos de São Pã.

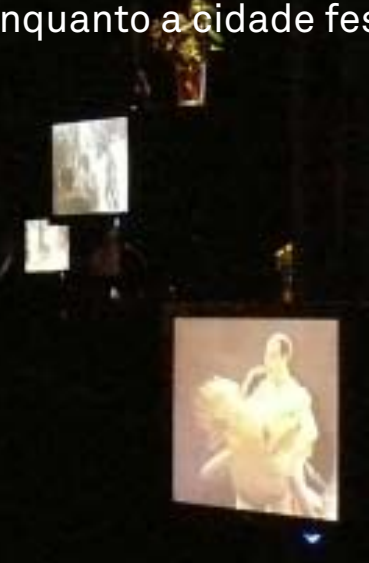

12- Audiência com a censura pra liberação do filme 0 Rei da Vela

1982

Duração: 06'37'”

- Audiência com̄ a censura pra liberação do filme

90 rei da vela.

Os censores discutem pontos polêmicos passíveis de proibição, como o tom do verde na bandeira brasileira e a utilização do Hino Nacionnal em ritmo de samba.

13- Traillers

Taniko, O Rito do Mar

Vento Forte pra um Papagaio Subir

Os Sertões

$2007 / 2008$

O ano de 2008, ano do cinqüentenário, teve produção incessante de espetáculos. Aqui são apresentados uchtraillers de Taniko - 0 rito do mar, peça do Nô Japonês cal bossa-nova traps-zênico; Vento forte pra um papagaio subir, peça de estréia da Companhia que teve uma recriação para as comemorações e Os sertões de Euclides da Cunha que viajou para Salvador, Recife, Rio de Janeiro, Quixeramobim e Canudos. 
SALA 3

14- Manifesto Merda

2007

Duração: 14'31"

Reunião dos movimentos de arte viva de São Paulo, para a luta para a construção do Anhangabaú da Feliz Cidade:Teatro de Estádio, Universidade Popular Antropofágica e Oficina de Florestas. Zé Celso, no fim de uma apresentação de A Terra, paramentado de Antônio Conselheiro, lê o manifesto.

\section{5- Satisfaction}

Processo de trabalho de Os Sertões 2006

Duração: 01'34"'

Os sertões foi um processo contínuo de trabalho por sete anos, com mais de cem pessoas envolvidas, com origens artísticas diferentes e heterogeneidade de classe, formação, nacionalidade...

Um processo deliciosamente complexo e instável.

Satisfaction é um vídeo de Gabriel Fernandes, que bem humoradamente editou um "barraco" no final de uma apresentação da Luta 2, em junho de 2006.

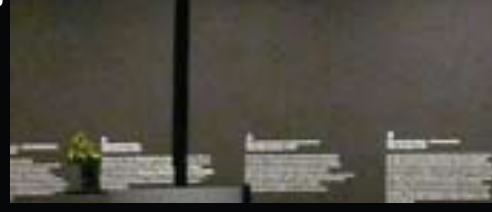

16- Soneto do Olho do Cú

As Boas, de Jean Genet

1992

Duração: 02'09"

Musica de Zé Miguel Wisnik para a trilha sonora de As boas, de Jean Genet. Dueto de Zé Celso e Marcelo Drummond cantado no espetáculo de 1992 no Centro Cultural São Paulo. É a estréia de Marcelo como ator.

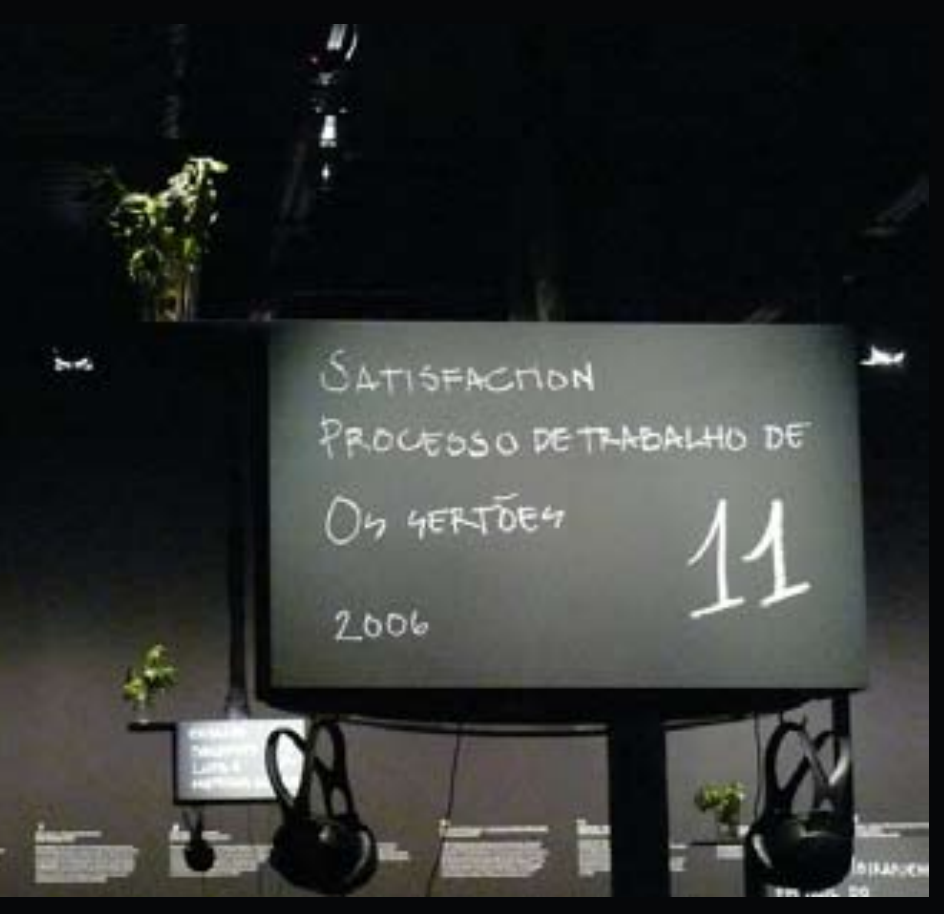




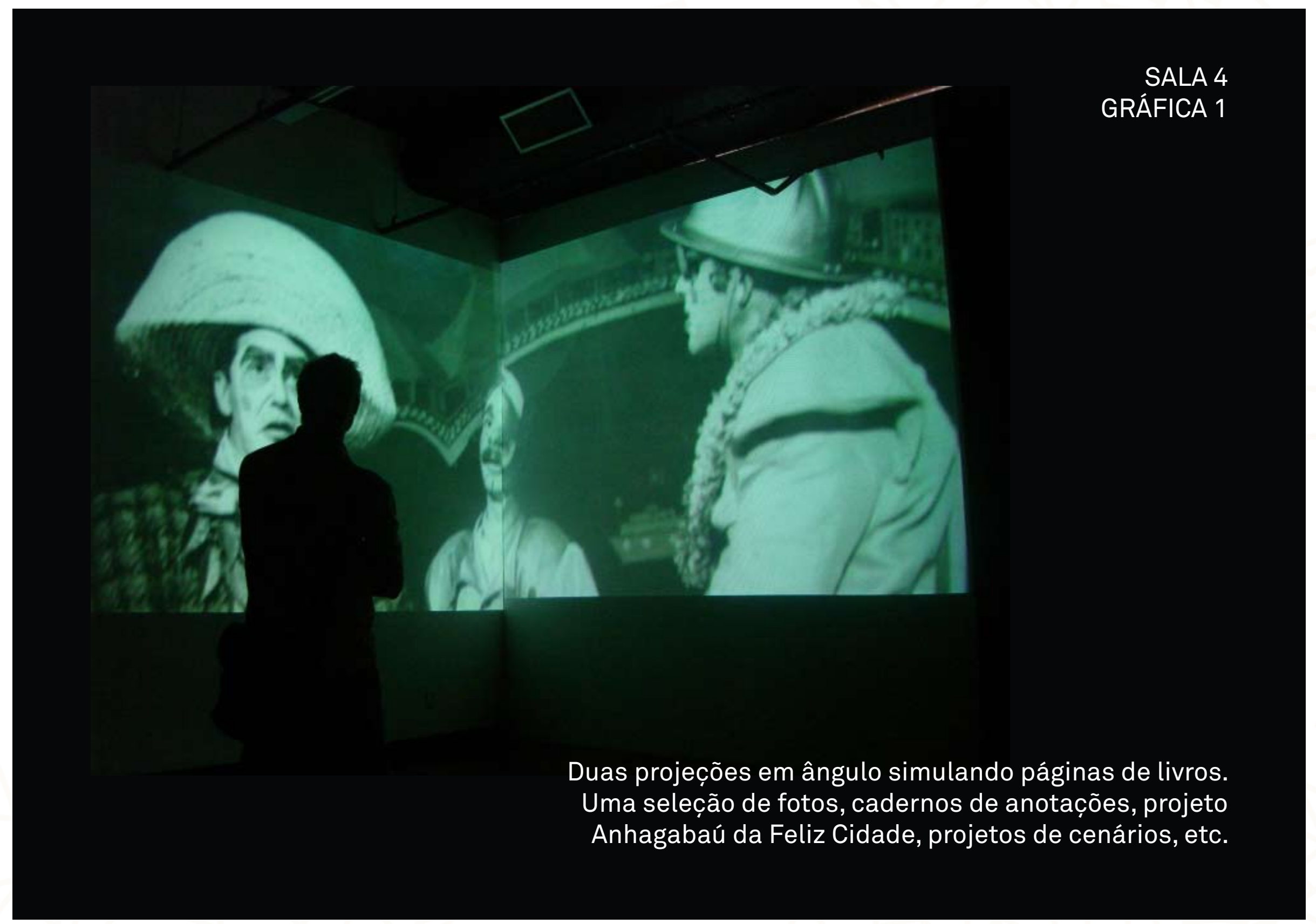




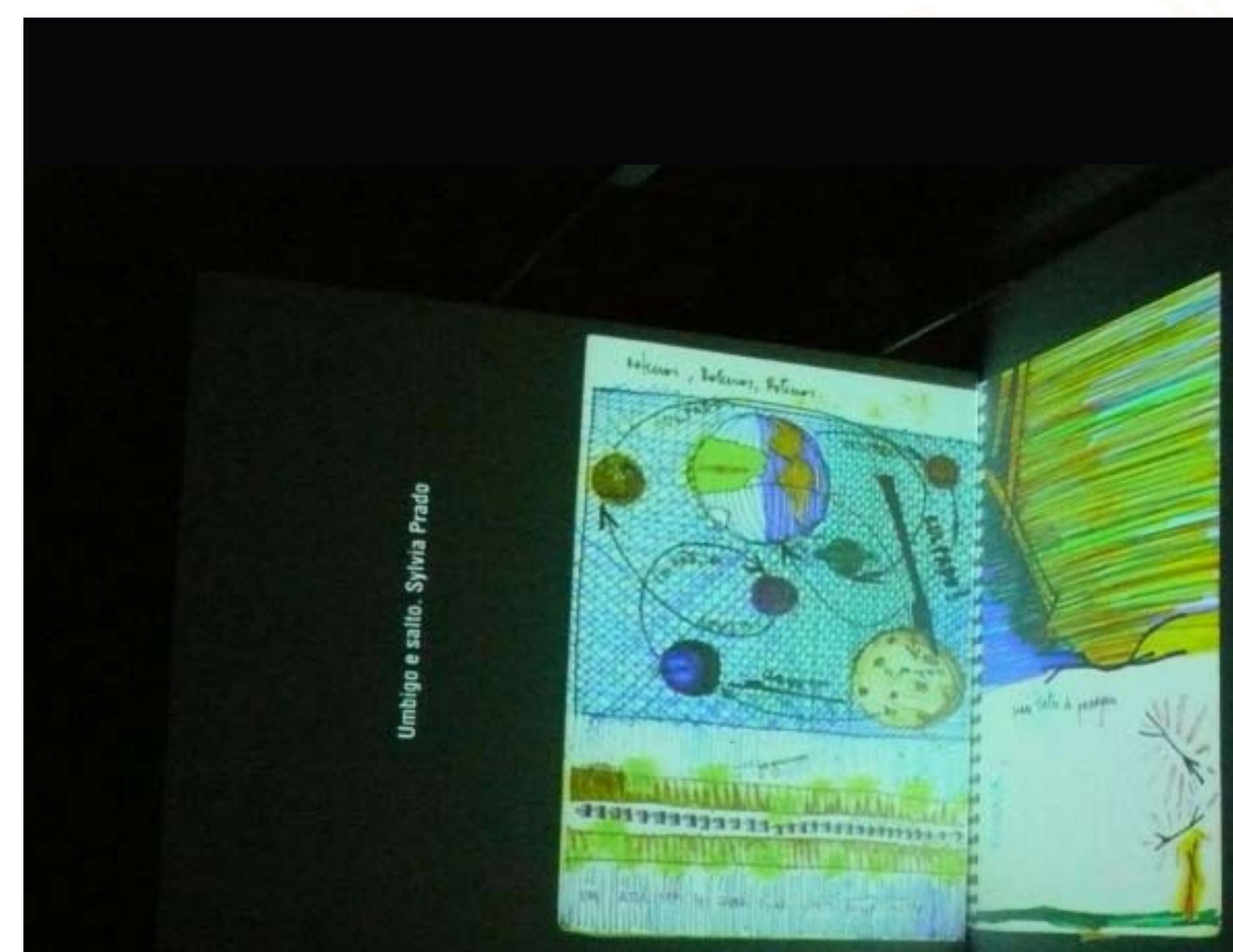



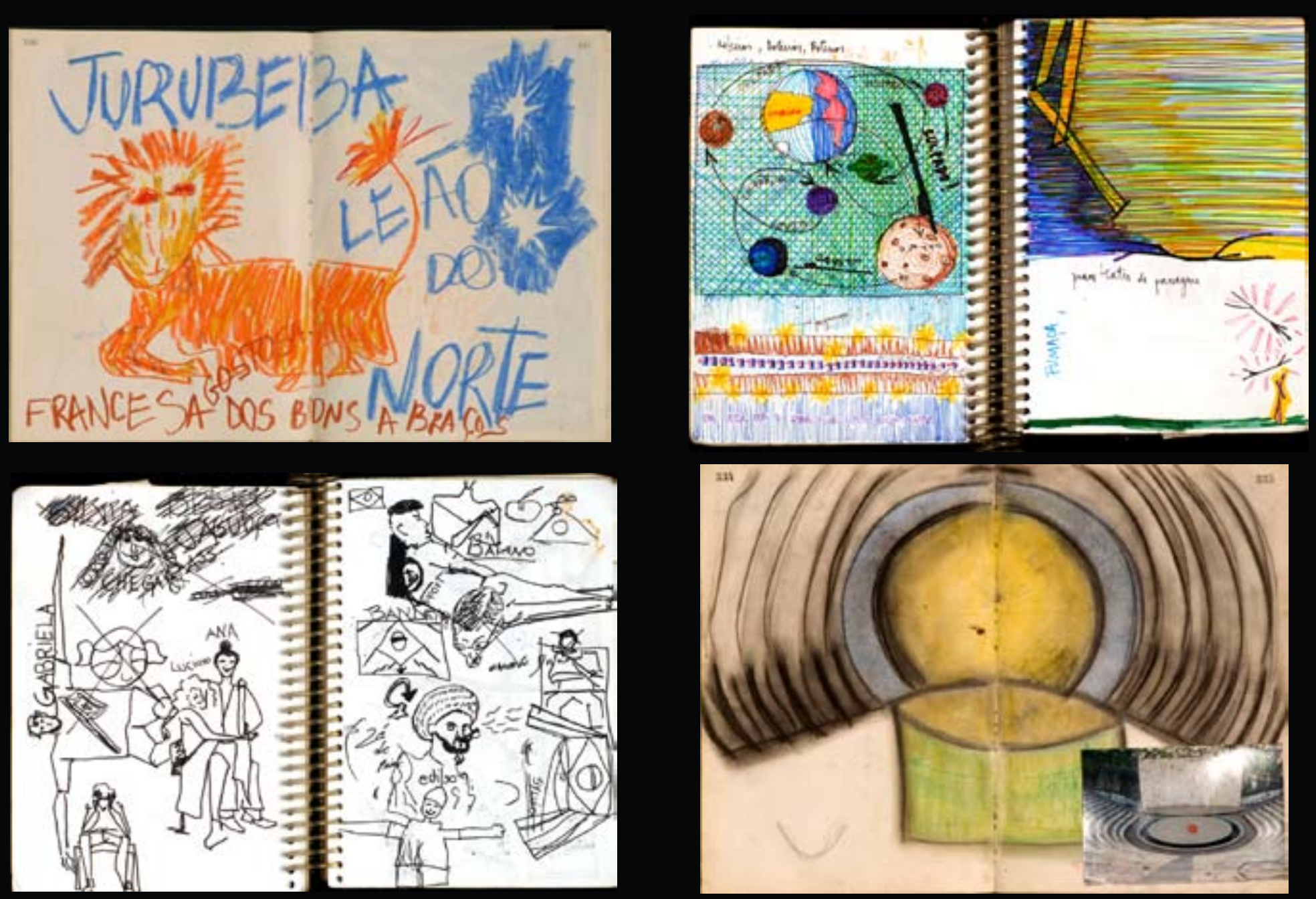

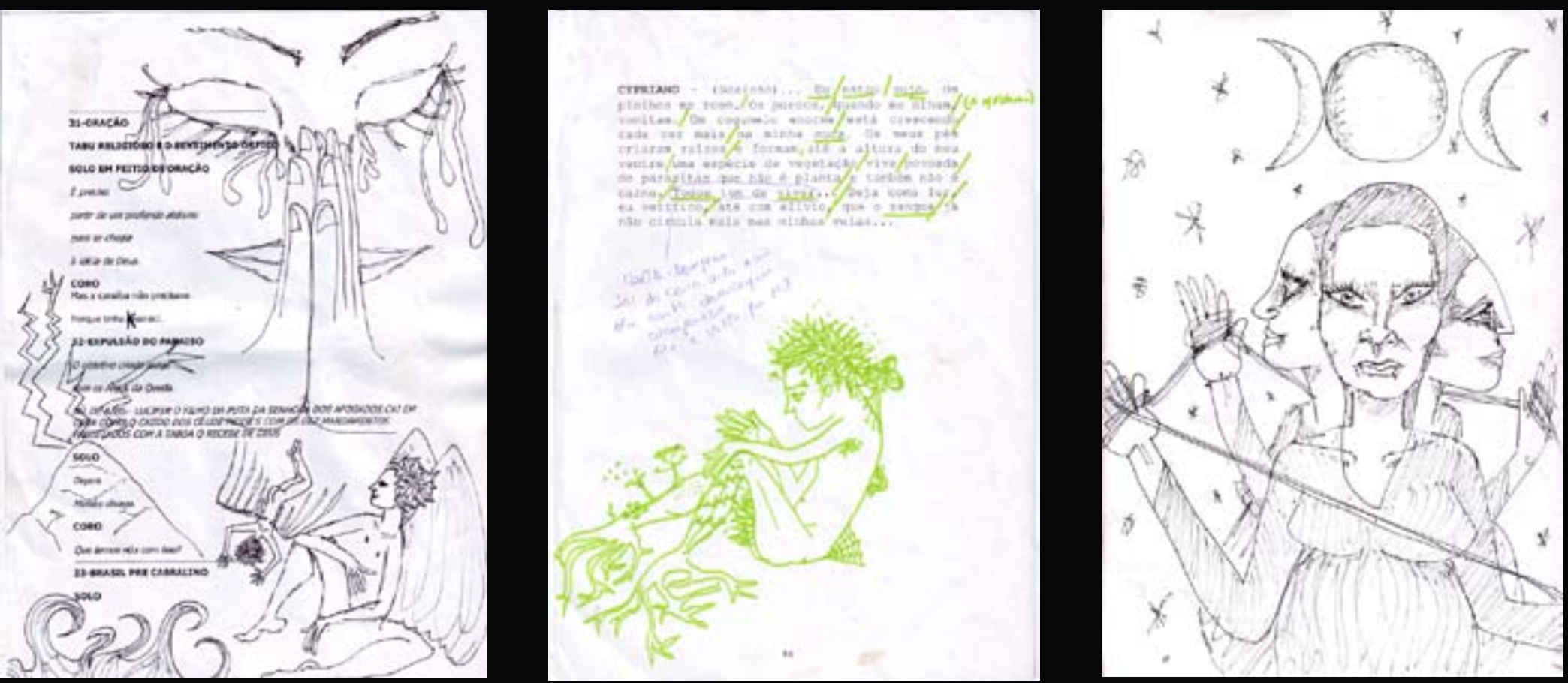

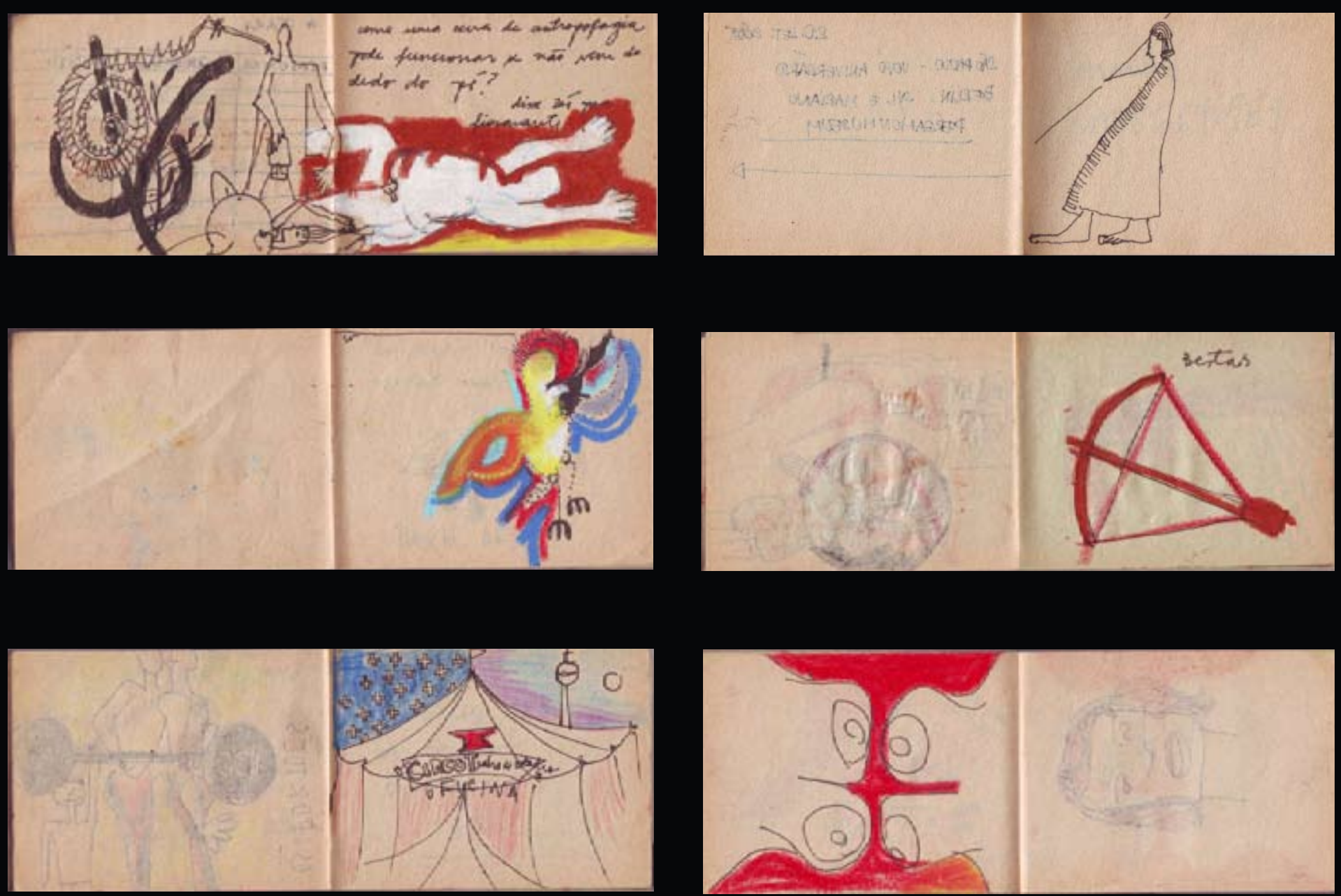

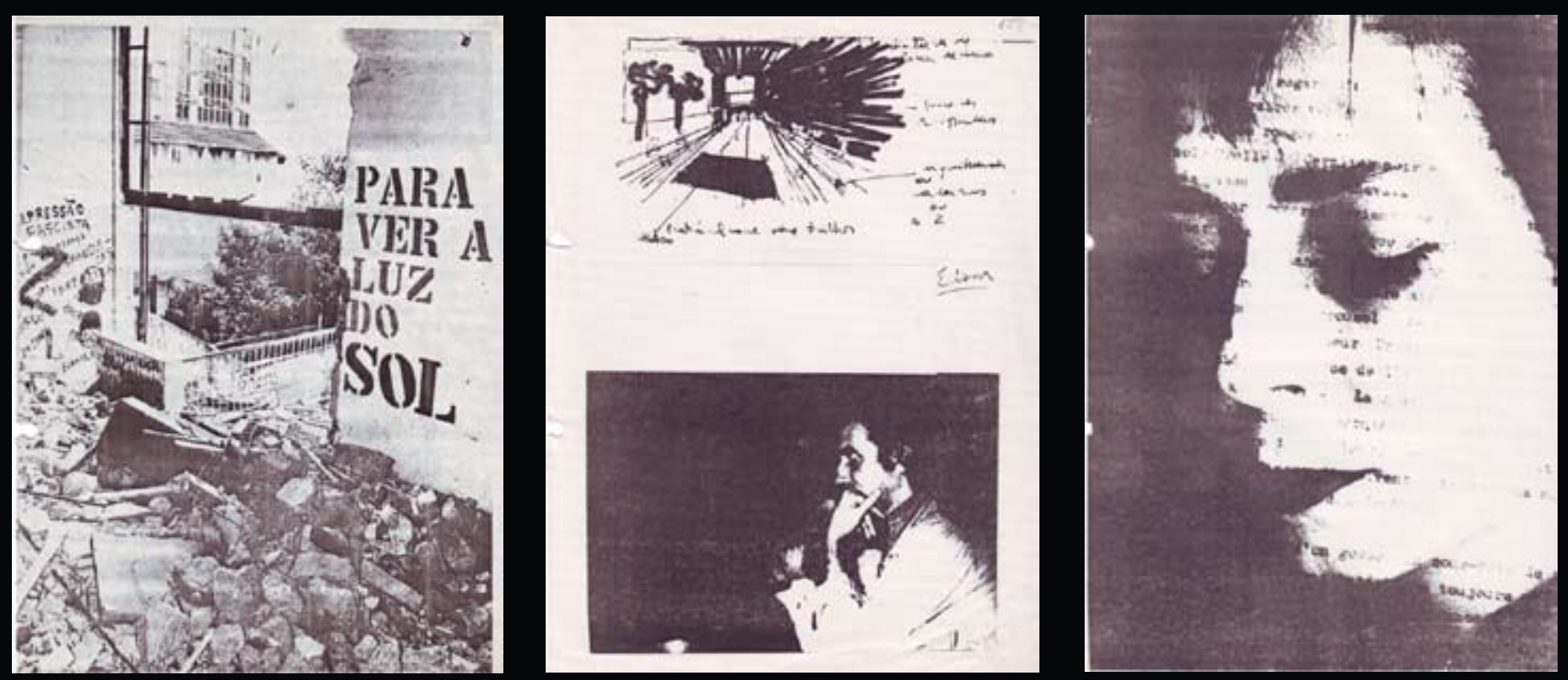


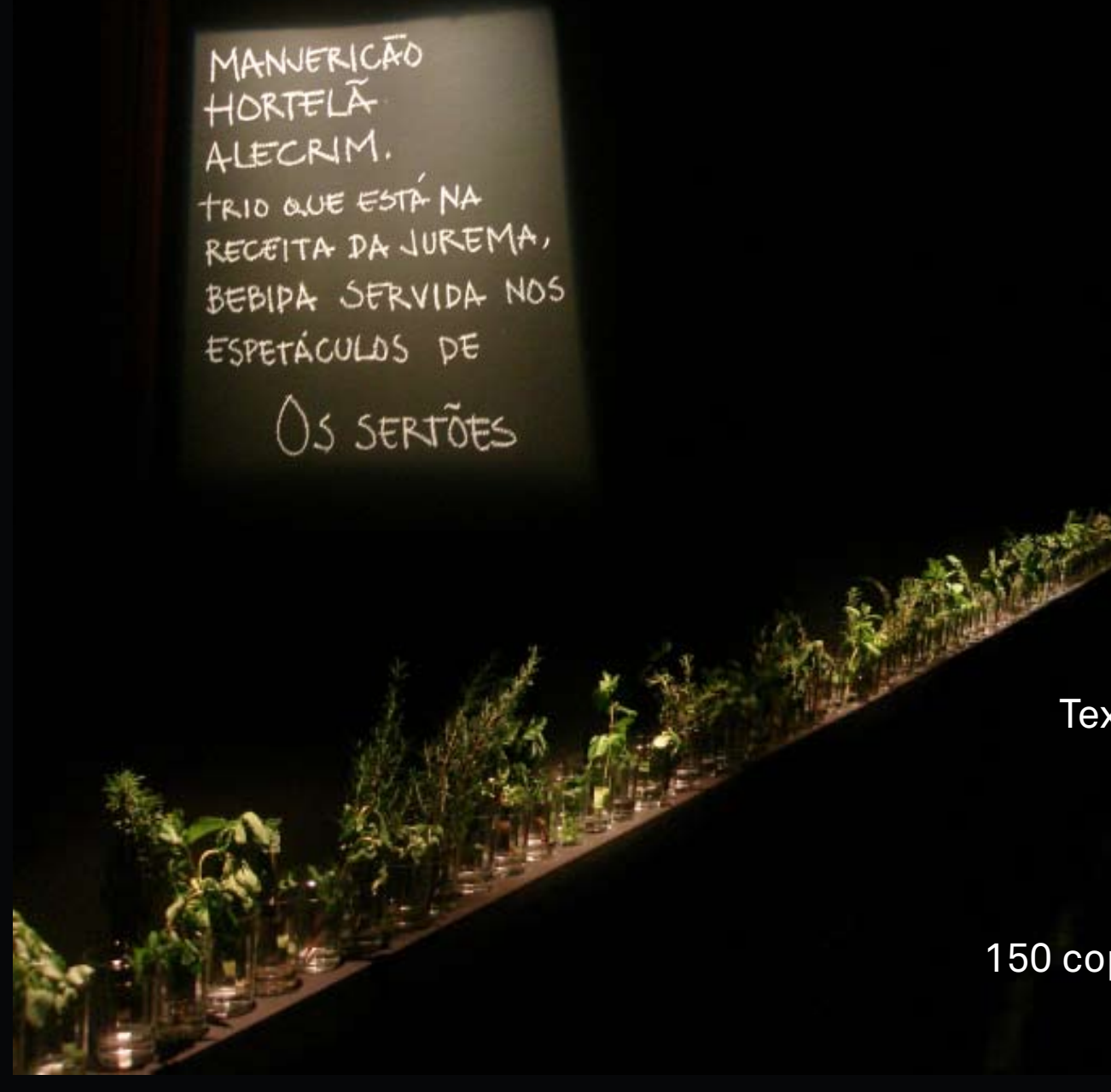

Texto sobre o tombamento do Teatro Oficina plotado na parede. Instalação: uma prateleira com copos de água e ervas (manjericão, hortelã e alecrim) Texto sobre as ervas plotado na parede

Especificações técnicas: 2 projetores 2500 Ansi Lumens 2 dvd player 150 copos de água com ervas (manutenção 2 a 3 vezes por semana) Prateleira, Plotagem 
Duas projeções em ângulo simulando páginas de livros.

Uma seleção de fotos, cadernos de anotações, projeto Anhagabaú da Feliz Cidade, projetos de cenários, etc.

Cronologia dos 50 anos do Teatro Oficina plotada na parede.

Instalação: pipocas em cestos de palha

Texto sobre o projeto Anhagabaú da Feliz Cidade xerocado e texto sobre a pipoca plotado na parede:

$$
\begin{aligned}
& \text { PIPOCA } \\
& \text { CampA pe aMouO/ }
\end{aligned}
$$

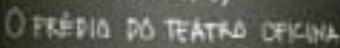

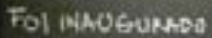

$$
\begin{aligned}
& \text { No his } 16 \text { se ACOHT be } 144
\end{aligned}
$$

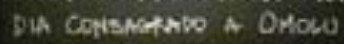

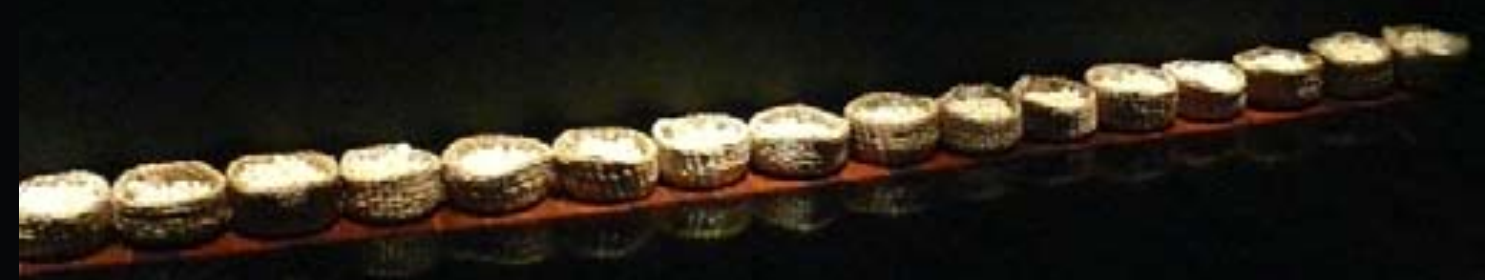


Especificações técnicas:

2 projetores 2500 Ansi Lumens

2 dvd player

30 cestos de palha com pipoca

Plotagem

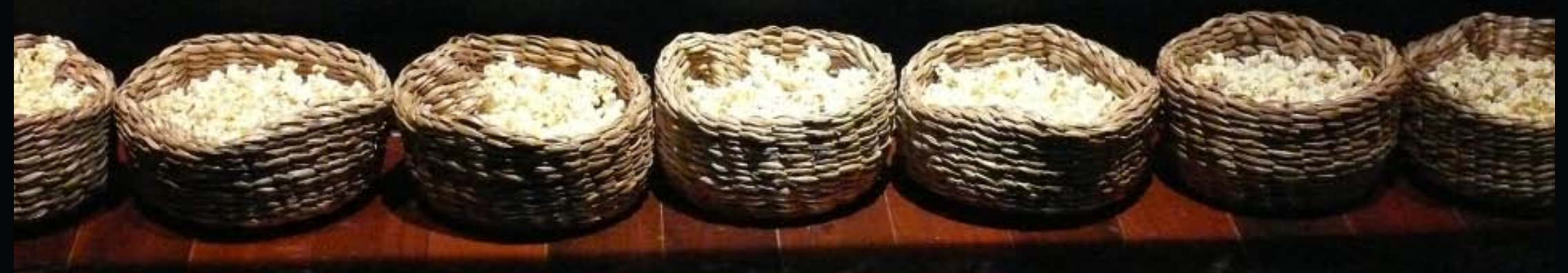

